\title{
10
}

\section{Palaeobotany and the early development of agriculture on Rapa Island}

\author{
Matiu Prebble \\ Department of Archaeology and Natural History, The Australian National University, and Nga Pae o te \\ Maramatanga Trust, University of Auckland, New Zealand, matiu.prebble@anu.edu.au \\ Atholl Anderson \\ Department of Archaeology and Natural History, The Australian National University
}

\section{Introduction}

Palaeobotanical studies in tropical and subtropical Remote Oceania have established broad records of vegetation and climate change covering the past 6000-7000 years. They mostly have used sedimentary deposits from large, closed depositional basins such as high-elevation bogs or volcanic caldera lakes in the tropical Hawaiian Islands (Selling 1948; Selling in Massey 1979; Athens and Ward 1993) and subtropical Easter Island (Flenley 1979; Flenley and King 1984; Flenley et al. 1991), and numerous bogs in northern New Zealand. While these records have provided good regional pictures of vegetation change, including the effects of fire and increases in seral pollen and charcoal particles that have been interpreted as indicating human activity, rarely have they revealed more direct evidence of the introduction of agriculture. As a result, many palaeoecological studies that argued the case for or against evidence of agriculture, and its associated age, came under criticism for a lack of direct proxies of human activity, imprecise chronology, and the sensitivity of the biological proxies to natural disturbance (e.g. Anderson 1994, 1995; McGlone and Wilmshurst 1999).

For these and other reasons, views on the significance of agriculture to Remote Oceanic colonisation have tended to be polarised. Kirch and Green (2001), primarily on linguistic grounds, argued that when humans first expanded into Remote Oceania around 1000 BC they brought a complete roster of domestic animals (dog, pig and fowl), plus commensal rats and other small vertebrates, and oceanic crops including taro (Colocasia esculenta), yam (Dioscorea spp.), bananas (Musa spp.) and breadfruit (Artocarpus altilis). These were thought essential to the colonisation process, particularly in the islands east of the Solomon Group, where the number of plant genera and the natural distribution of economic plants declines dramatically, forming 
what Jones and Spriggs (2002) have described, somewhat extravagantly, as a 'green desert'. The necessity of agriculture to colonisation of Remote Oceania has been questioned (Davidson and Leach 2001) and asserted (Addison 2008) on nutritional grounds.

The concept of 'transported landscapes' (sensu Anderson 1952) has been employed by Kirch $(1982,2002)$ to emphasise the motivation behind ecological transformation of islands in Remote Oceania, in which a newly occupied ecosystem was rapidly reshaped to operate in much the same way as the homeland ecosystem. Anderson (2003, 2009a, b), conversely, has argued that the distribution of oceanic crops and domestic animals is very patchy across Remote Oceania, especially in the more remote islands, and that this is a function of the increasing difficulty of transportation eastward and southward. As a result, some islands had no access, or limited access, to agriculture, and others in which it was well established by the historical era had probably created such landscapes by long-term accumulation of taxa rather than during initial colonisation. Of course, some islands, largely by geographical circumstance, were able to institute agricultural economies from almost the beginning of settlement.

Models aside, it remains the case that the importance and sources of vegetable carbohydrates to early populations in Remote Oceania are poorly known and enigmatic, even in very wellstudied instances, such as in Vanuatu where stable isotope records from the Teouma burial site on Efate indicate that around $800 \mathrm{BC}$ the diet was dominated by terrestrial and marine protein sources, with only a minor contribution from vegetable foods (Valentin et al. 2010). Whether these were of introduced taxa is uncertain because the identification of starch grains, found on stone tools and pots from archaeological deposits in Vanuatu (Horrocks and Bedford 2005; Horrocks et al. 2009), is open to question on several methodological grounds (e.g. Hardy et al. 2009; Wilson et al. 2010).

Turning to the role of terrestrial palaeoecological records, it is necessary to acknowledge that, in tropical regions especially, the nature of fossil proxies, the state of preservation, the degree of chronological resolution and the completeness of the deposits can be highly variable. Prebble and Wilmshurst (2009) argued that multiple proxies for human activities, primarily agricultural production, are more often preserved in sites close to where such activities occurred and that site selection is critical for addressing questions about agricultural expansion. In considering active taro (Colocasia esculenta) gardens built on deep organically rich sedimentary deposits underlying Maunutu Swamp on Rimatara (Austral Islands, French Polynesia), they found that such deposits needed to be treated like archaeological profiles, as the various proxies accumulated under different sets of conditions influenced by human activity. Artefacts, including garden stakes and animal tethers, from the Rimatara deposits emphasised the inherent archaeological character of the deposits. The physical mixing of sedimentary strata by digging, both in the past and present, has increased the likelihood of obtaining unreliable radiocarbon chronologies. Despite these potential problems, the array of fossil proxies available from these sites can reveal important insights into the changing biodiversity of garden systems.

Rapa Island offers a case study of the initiation of agricultural activity in the early phase of human colonisation. Kennett et al. (2006), Prebble and Dowe (2008) and work as yet unpublished have identified multiple proxies for ecological change from Tukou Swamp, on Rapa, spanning the past 7500 years. Preserved Pandanus tectorius syncarps and high concentrations of Pandanus pollen characterise the pre-human swamp record. A coastal swamp forest developed on top of estuarine sediments between $2000 \mathrm{BC}$ and $\mathrm{AD}$ 1000. In the past 750 years, unprecedented increases in charcoal particle concentration and seral fern spores, plus a rapid decline in Pandanus pollen, indicate early forest clearance. A number of plant species became extinct, including a palm tree (Prebble and Dowe 2008). The interpretation of cultural activity after about AD 
1200 is strengthened by the near-synchronous appearance of pollen from the introduced plant cultigen Colocasia esculenta, and of weeds indicative of the expansion of agricultural activity.

Here we extend this analysis by outlining the availability of indigenous food plants and historical evidence of agriculture, and then focus on the development of agriculture at Tukou Swamp by examining the chronology of introduction and expansion of Colocasia across the site. We highlight some of the complexities and the potential of palaeobotanical analyses for understanding the role of agriculture in the colonisation of one of the more remote islands of Remote Oceania.

\section{Indigenous carbohydrate sources on Rapa}

Understanding the extent of indigenous carbohydrate-rich plants (i.e. those plants that have not been introduced) is one means of assessing the potential of indigenous food sources to sustain growing human populations. The natural distribution of some of the main oceanic root and tree crops is limited to the Western Pacific. Most of the remote Pacific Islands, including Rapa, lacked bananas (Musa spp.), yams (Dioscorea spp.), taro (Colocasia esculenta), rhizome crops including the gingers (e.g. Curcuma longa and Hedychium flavescens) and tree crops including Syzygium malaccense, Burkella obovata, Barringtonia edulis and Inocarpus fagifera. What, then, was available on Rapa?

Based on a summary of the pre-human fossil data from Tukou Marsh (Prebble unpublished data) and survey data of the existing flora of Rapa (Meyer 2002), the variety of indigenous carbohydrate, fat and sugar sources from vascular plants available at initial human arrival can be defined (Table 10.1). Which species would have provided an adequate staple food or supplement to an otherwise protein-rich diet at the advent of people cannot be deduced from this list, and some plants that potentially served as important fat and carbohydrate sources are missing from it. This is merely a partial guide to the potential sources.

Coconut trees are indigenous on many islands in Remote Oceania at least as far east as Tubuai in the Austral Archipelago, but they are not indigenous to the Hawaiian Archipelago or Rapa (Prebble and Dowe 2008). The distribution of coconut trees is partly controlled by rainfall, as fruits remain unviable in areas or in years with less than $1000 \mathrm{~mm}$ annual precipitation (Fosberg 1956). The distribution of pigs in the initial colonisation of Remote Oceania may have been limited in part by the distribution of coconut, particularly the domesticated, large-fruited trees. Most of the wild-type indigenous coconuts that were established on the more remote Pacific Islands would have possessed very small fruits with minimal endosperm (Prebble and Dowe 2008) and they may not have provided an adequate source of protein, vegetable fat and carbohydrate to sustain pig husbandry and growing human populations (Kirch 2002). Dried coconut meat (endosperm) from domesticated coconut consists of around $20 \%$ carbohydrate, including soluble sugars, sucrose and starch (Jayalekshmy and Mathew 1990). Large servings to satisfy daily requirements of carbohydrate would require domesticated large-fruit varieties. Coconuts occurred rarely (Chapter 2), if at all, prehistorically on Rapa.

Another carbohydrate and fat source would have been provided by the seeds of Pandanus tectorius, which, from fossil pollen, appears to have been very common across the remote Pacific Islands including Rapa, particularly on islands that lacked mangroves in estuaries and backswamps. Generally, Pandanus forms monospecific stands with a sedge/herb-dominated understorey (Ash and Ash 1984), but no 'true' mangrove species occur east of the Cook Islands (Ellison 1991). On Rapa, P. tectorius appears to prefer a mangrove habitat, forming dense stands along the few margins of tidal flats where human activity has not been prominent. Other Pandanus species may be indigenous to Rapa; for example, St. John (in Fosberg and St. John 
Table 10.1. Fossil taxa with potential food value identified from Tukou deposit in pre-human aged sediments older than AD 900 are listed. Also listed are the possible representatives of the fossil taxa found in the modern flora of Rapa and the biogeographic affinity of taxa. Extant indigenous taxa without fossil records that may provide some food value are also listed (data sources from Meyer 2002).

\begin{tabular}{|c|c|c|c|c|}
\hline Fossil taxa & Family & $\begin{array}{l}\text { Indigenous representatives in } \\
\text { modern flora }\end{array}$ & Biogeographic affinity & $\begin{array}{l}\text { Carbohydrate, sugar } \\
\text { and fat sources }\end{array}$ \\
\hline Angiopteris & Angiopteridaceae & Angiopteris rapensis, A. Iongifolia & Indo-Pacific/endemic & pith and root \\
\hline Apiaceae & Apiaceae & Apium australe & Indo-Pacific & root \\
\hline $\begin{array}{l}\text { Arecaceae: Arecoideae } \\
\text { type }\end{array}$ & $\begin{array}{l}\text { Arecaceae, subfamily } \\
\text { Arecoideae, tribe } \\
\text { Iguanurinae }\end{array}$ & extinct & $?$ & fruit and young shoots? \\
\hline Celtis & Ulmaceae & Celtis pacifica & Indo-Pacific & fruit \\
\hline Coprosma & Rubiaceae & $\begin{array}{l}\text { Coprosma cookei, C. rapensis Coprosma } \\
\text { spp. Possible extinct species }\end{array}$ & Pacific/endemic & fruit \\
\hline Cyathea & Cyatheaceae & $\begin{array}{l}\text { Cyathea affinis, C. medullaris, C. } \\
\text { rapensis, C. stokesii }\end{array}$ & Indo-Pacific/endemic & pith \\
\hline Cyperaceae- & Cyperaceae & numerous species & pan-tropical, cosmopolitan & root \\
\hline Davallia/Histiopteris & $\begin{array}{l}\text { Davalliaceae/ } \\
\text { Dennstaedtiaceae }\end{array}$ & numerous species & pan-tropical, cosmopolitan & root \\
\hline Dryopteridaceae & Dryopteridaceae & numerous species & pan-tropical & root \\
\hline Freycinetia & Pandanaceae & Freycinetia arborea & Indo-Pacific & fruit and root \\
\hline Hypolepis & Dennstaedtiaceae & Hypolepis punctata, H. tenuifolia & Indo-Pacific/Pan-tropical & root \\
\hline $\begin{array}{l}\text { Malvaceae } \\
\text { undifferentiated }\end{array}$ & Malvaceae & numerous species & $?$ & shoots? \\
\hline Monolete Psilate & $?$ & numerous species & $?$ & root \\
\hline Monolete undiff. & $?$ & numerous species & $?$ & root \\
\hline Myrtaceae undiff. & Myrtaceae & numerous species & $?$ & fruits? \\
\hline Pandanus cf. tectorius & Pandanus & Pandanus tectorius & Indo-Pacific/endemic? & fruits \\
\hline Pteris & Pteridaceae & numerous species & $?$ & root \\
\hline Polypodiaceae & Polypodiaceae & numerous species & $?$ & root \\
\hline Rubiaceae & Rubiaceae & numerous species & $?$ & fruit? \\
\hline Trilete Psilate & $?$ & numerous species & $?$ & root \\
\hline Trilete undiff. & $?$ & numerous species & $?$ & root \\
\hline Urticaceae/Moraceae & Urticaceae/Moraceae & numerous species & $?$ & shoots? \\
\hline \multicolumn{5}{|c|}{ Extant indigenous taxa without fossil records } \\
\hline Tetragonia tetragonioides & Aizoaceae & Tetragonia tetragonioides & $\begin{array}{l}\text { temperate/sub-tropical } \\
\text { Pacific }\end{array}$ & leaves \\
\hline Capparis sp. & Capparaceae & Capparis sp. & Indo-Pacific & fruit \\
\hline Leptecophylla rapae & Ericaceae & Leptecophylla rapae & endemic & fruit \\
\hline Vaccinium rapae & Ericaceae & Vaccinium rapae & endemic & fruit \\
\hline Astelia rapensis & Liliaceae & Astelia rapensis & endemic & fruit \\
\hline Macropiper puberulum & Piperaceae & Macropiper puberulum & indigenous & fruit \\
\hline
\end{tabular}


1934) recorded 13 species of Pandanus in 1934, although Smith (1979) and Stone (1988) suggest many of these are simply varieties of $P$. tectorius. In examining the genus on Tahiti, Stone (1988) could not discount the human introduction of additional Pandanus species or P. tectorius varieties and this also may have been the situation on Rapa.

Fern roots and pith could have served as an important substitute for tropical root crops at the time of initial Polynesian arrival, especially in sub-tropical or temperate environments (McGlone et al. 2005). Tree-fern pith (particularly of Cyathea medullaris) is still consumed on Rapa (Freddy Riaria pers. comm. 2002) and it might have provided an important starch source, given the likely former abundance of these trees at the time of human arrival on the island. Other ferns with large piths include Marrattia spp. and Angiopteris spp., the latter having a restricted distribution in Remote Oceania. It is unclear how abundant ground ferns including Histiopteris incisa, Dryopteris sp. and Dicranopteris linearis were prior to human arrival, but with cultural burning these plants would have become widespread along forest margins, providing an abundant but rudimentary starch source.

Algae may have provided a source of carbohydrate to the first colonists of Remote Oceania. Algal material is found in some archaeological middens in Remote Oceania (e.g. Kirch et al. 1995), but the extent of consumption is unclear (Conte and Payri 2006). Small fragments of algae were found in the Tangarutu deposit on Rapa, but the possibility that they were blown in cannot be excluded.

\section{Historical observations of agriculture on Rapa}

Although nobody landed from the Discovery in 1791, the vessel spent some time close inshore and Vancouver thought Rapa conspicuous by the lack of Cocos nucifera (described as the 'cocoanut' palm). He did not see any Colocasia esculenta pondfield production systems, perhaps because observation of the inland valleys was obscured by thick vegetation along the coastline. Vancouver (in Lamb 1984:215) recorded that:

... they [the islands] were chiefly clothed with shrubs and dwarf trees. Neither the plantain [Musa spp.] nor other spontaneous vegetable productions common to the inhabited tropical islands, presented themselves.

Menzies (in Shineberg 1986:65-66) noted some plants that were used in the clothing of Rapan men who came out to the ship:

The only cloathing they wore were a narrow slip of cloth made from the bark of a tree [prob. Talipariti tiliaceum syn. Hibiscus tiliaceus but potentially Broussonetia papyrifera] which passed round their waist \& between their legs, this cloth appeard to be a very scarce article amongst them as many of them had not sufficient of it to cover their nakedness, it was evident however that they generally wore something for that purpose, as some of them had bunches of leaves of a species of Dracena [prob. Cordyline fruticosa] suspended to a girdle round their middle for that intention.

Only three or four plant species may be inferred from the descriptions provided in both accounts. More general comments were made regarding the status of the island's vegetation, including the impoverished state of the forests and absence of coconut palms, as summarised here by Menzies (in Shineberg 1986:67-68):

The valley round the bottom of the Bay is tolerably pleasant when compard with other parts of the Island being scattered over with Bushes among which we could perceive the habitations of the Natives $\&$ some little signs of Cultivation, the hills behind $\&$ on the South Side of it appeard thinly coverd with some verdure $\&$ here $\&$ there wooded with some scrubby Trees particularly in the hollow places between 
the hills, but they seemed of no great magnitude. Towards the North end the hills are not so rugged \& rocky but ascend with a smooth surface coverd with grass \& destitute of Trees or bushes of any kind. We observed no Cocoa Nut Trees [Cocos nucifera] anywhere on the Island.

In 1924, Stokes (m.s. Group 2 Box 7.1) spent most of the year compiling an ethnography of the island but also recorded the recollections of the islanders and made many useful observations of agricultural systems. He remarks that 'in early days cultivation was confined almost entirely to the wet-land taro'. He quotes Davies (1827), who in 1826 'inspected the plantations of taro, which were all laid out, and display a degree of skill and contrivance evinced in nothing else we saw'. He also quotes Davies who found that: 'One coconut palm was reported as present from a drift and was not recognized by the local natives.' Stokes (m.s. Group 2 Box 7.2) also reported in 1924 that:

There are now many coconut palms scattered through the island, which though vigorous and grown to a fair height, according to report, drop their fruit before it matures. Other introductions at Tupuaki, on the northern coast, are said to have borne fruit that was 'killed by thunder' perhaps to a cold storm. A white man who has tried to grow coconuts for commerce at the northern end of the harbor apparently abandoned the venture as a failure. It is evident that Rapa is too cold for the successful production of coconuts, but that the palms will grow in many parts of the island, and will occasionally produce fruit. The non-recognition of the coconut palm by the natives, reported by Davies, points very suggestively to the fact that the palm was unknown to the ancestors of the Rapa people.

Of taro agriculture, Stokes provides an intriguing account of hand digging of pondfields, commenting that 'most taro cultivation was done with the bare hands a method still used to a remarkable extent. Once the pond is prepared, the hand is really more suitable for taro cultivation than any tool.' He also suggests that many areas of the island 'are dry and well-suited for the cultivation of sweet potato, which though present in the early days, was evidently of very little importance'. He goes on to comment on the cultivation of other crops:

Opinions differ as to the cultivation of bananas. Of other useful plants, there seem to have been cultivated only koali (gourd) and aute (paper mulberry). Seeds of the gourd are set in the ground with little preparation, and the plants are left to look after themselves. The growing of aute has been given up, but apparently in former days it was definitely cultivated. A dry-looking hill slope bordering the shore at Aupapa, Angairao Bay, is said to have been an aute field; the patches are small, narrow, irregular terraces following the contour of the land. At the bottom of the slope the soil is retained by a rough stone wall.

The benchmark for botanical observations of the island comes from an unpublished report of the B.P. Bishop Museum Expedition of 1934 by Harold St. John and Raymond Fosberg, but they made little comment about the varieties of plant cultigens or about the state of gardens on the island. Additional information about the distribution and character of modern taro pondfields is provided by Bartruff et al. in Chapter 13. From interviews with local gardeners in 2002, Motley (unpublished data) recorded 25 varieties of Colocasia esculenta known on Rapa. Of these, 20 were regarded as Polynesian introductions and the remaining five of recent introduction. A number of varieties are known to have been lost as a result of disease and probably neglect over the past decade, including 10 Polynesian varieties, as well as two recent varieties. Around six varieties are currently grown for popoi, a type of cooked taro formed by pounding and fermenting to create a thick paste that can be stored. 


\section{Study site: Tukou Marsh, Ha'urei Harbour, Rapa}

Ha' urei Harbour on Rapa represents the remnant of one of the original volcanic calderas formed during island orogeny in the Pliocene. The shallow bathymetry of the harbour suggests the entire area was exposed during glacial lowstand sea levels. The exposed reef at the harbour entrance, backed by calcareous reef shoals along the interior, currently restricts wave action from the sea, to the degree that the harbour could be described as a lagoon. At low tide, fine-grained sediments of a mixture of alluvial sediments, shell and coral detritus are exposed to reveal three prominent bird's-foot river deltas and tidal flats extending out from the high-tide shoreline (see Figure 10.1). Water depth surrounding the Tapuki (Tapu'i) basaltic islet in the centre of harbour is no more than $1.5 \mathrm{~m}$ below low-tide level.

Shoreward of the exposed deltaic sediments is a series of levee-backed marshes positioned at Tukou, Matataa and Aitoke (Figure 10.2). All of these sites have been heavily modified by human activity and grazing by cattle, horses and goats. A map of Ha'urei Harbour sketched in 1864 by John Vine Hall (1869) shows the position of a number of coastal pondfield systems

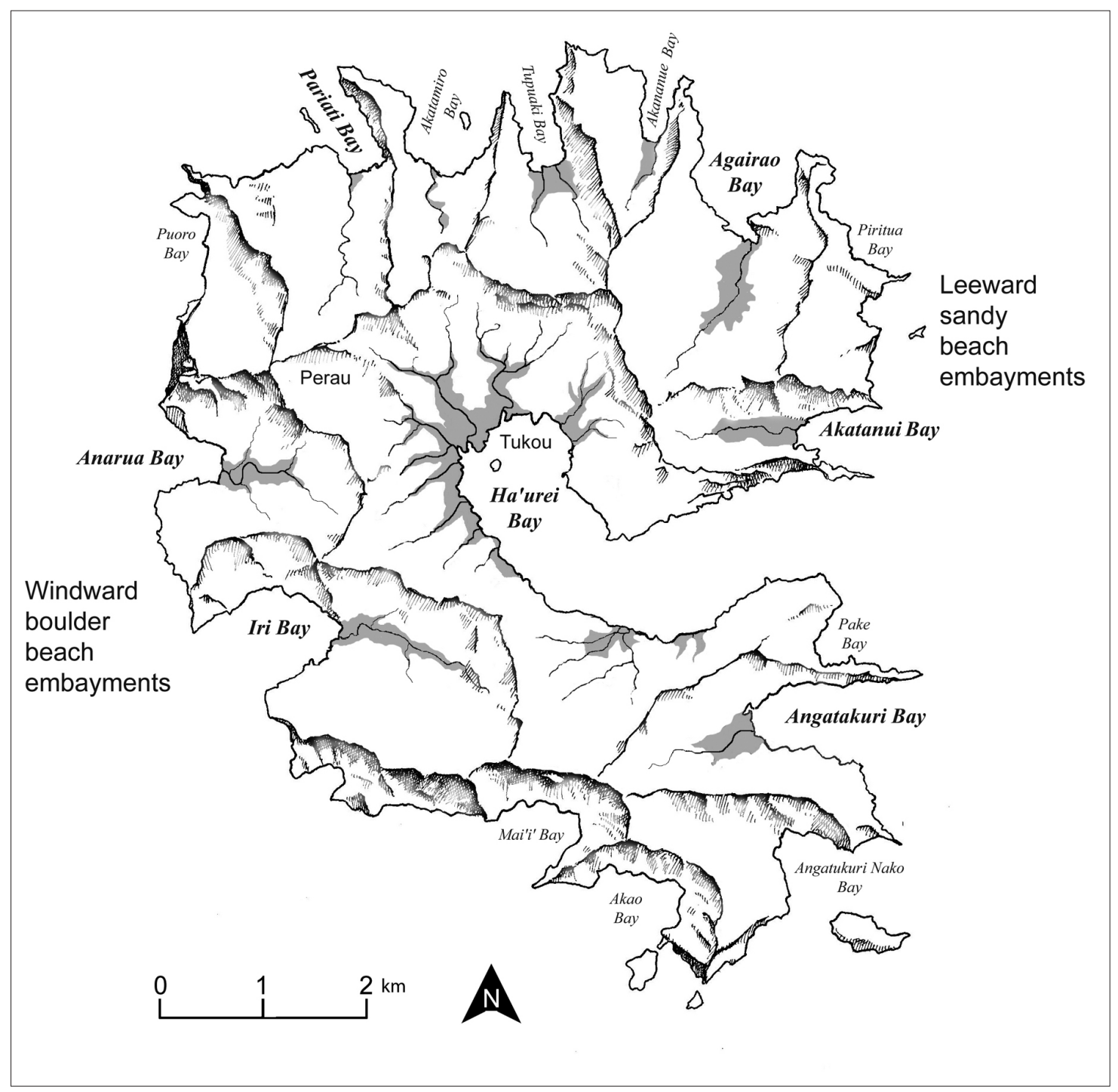

Figure 10.1. Map of Rapa showing the main windward boulder-beach and leeward sandy-beach embayments. The position of Tukou and the highest mountain peak (Perau, $650 \mathrm{~m}$ ) are also indicated. 
that were used for Colocasia esculenta cultivation (Figure 10.2). Remnant dry-stonewall terrace features are now interspersed within many of the levee-backed marshes, along the margins of riverbeds, or along the present shoreline. At certain points, these marshlands extend more than $100 \mathrm{~m}$ inland and rise to an elevation of more than $2 \mathrm{~m}$. On the most inland side, these marshes are bound either by river levees or steeply rising embankments of the surrounding hill slopes that appear to have been cut by a previous, probably mid-Holocene, sea-level high stand (Figure 10.3).

Tukou Marsh lies on the south side of the broadest river delta and associated tidal flats of Ha'urei Harbour. The marsh is banked and divided by two smaller prograding river channels, forming two waterlogged depressions. The central-most marsh depression was chosen for this palaeoecological study, and sediment cores were taken in 2002 (June-August). The modern marsh appears to have developed behind the southern levee of the main river, and the northern levee of the smaller river bounded the marsh to the south. The marsh extends from the estuarine shoreline, marked at high tide (ca. $0.4 \mathrm{~m}$ above mean sea level) by driftwood and estuarine detritus, ca. $135 \mathrm{~m}$ to the embankment of the surrounding hill slope. Below the embankment the marsh reaches a maximum elevation, based on laser transit measurements, of $3 \mathrm{~m}$ above the high-tide mark. The remains of an agricultural terrace complex rise an additional $50 \mathrm{~cm}$ or more above the marsh surface.

Overall, the climate on Rapa is subtropical to warm temperate. It receives around 2500$3000 \mathrm{~mm}$ annual rainfall, based on measurements taken from Ha'urei village, also at sea level (Rapa Meteo unpublished data). Tukou is fed by two permanent streams that drain the eastern catchment of the Perau-Namuere range, with water flow gradients averaging above 30 degrees. Hydrological data are unavailable for this catchment.

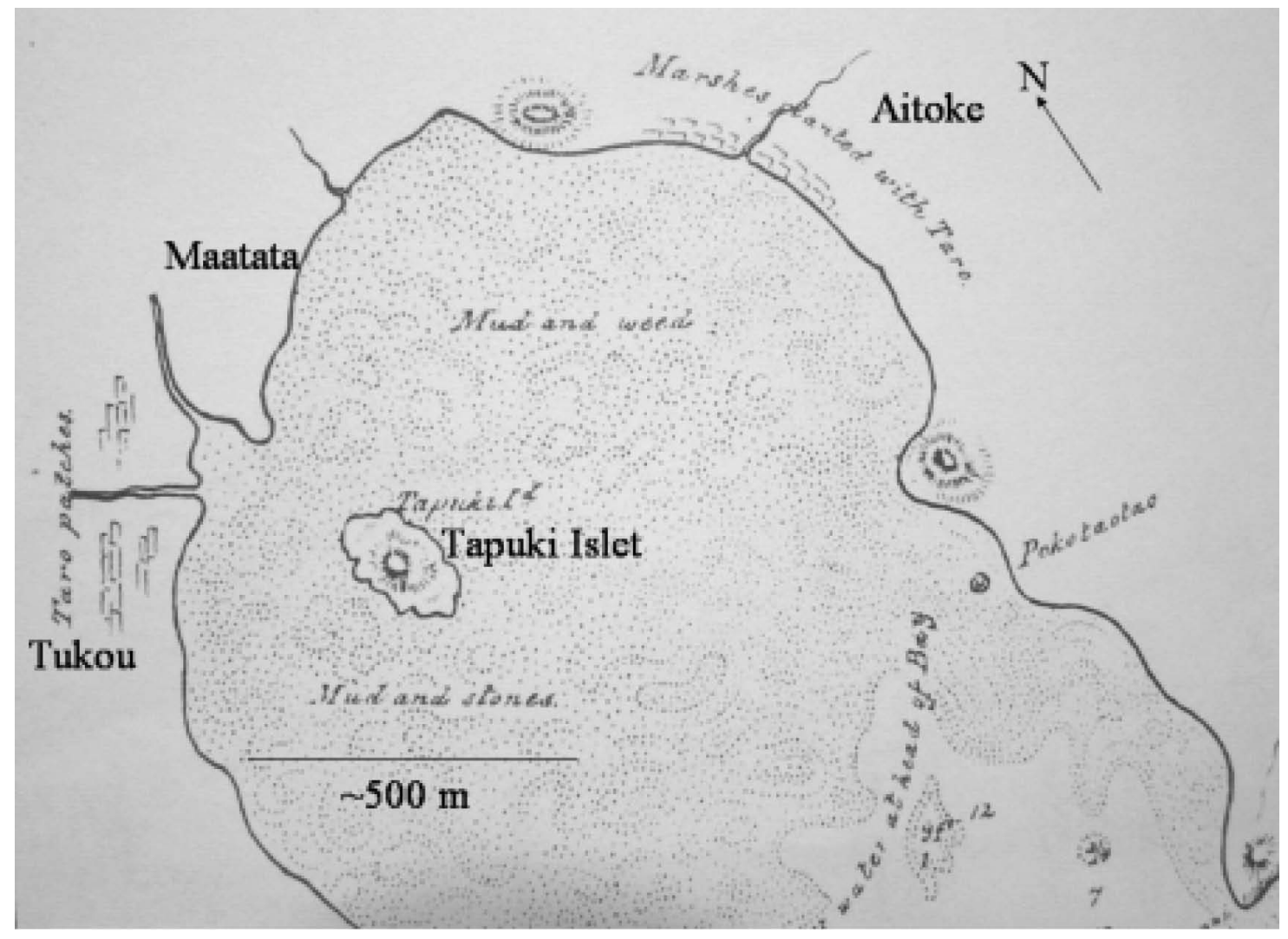

Figure 10.2. Section of a sketched map of the head of Ha'urei Harbour, Rapa, by John Vine Hall (1869a), showing the location of the main marsh systems ('Taro patches), including Tukou. 


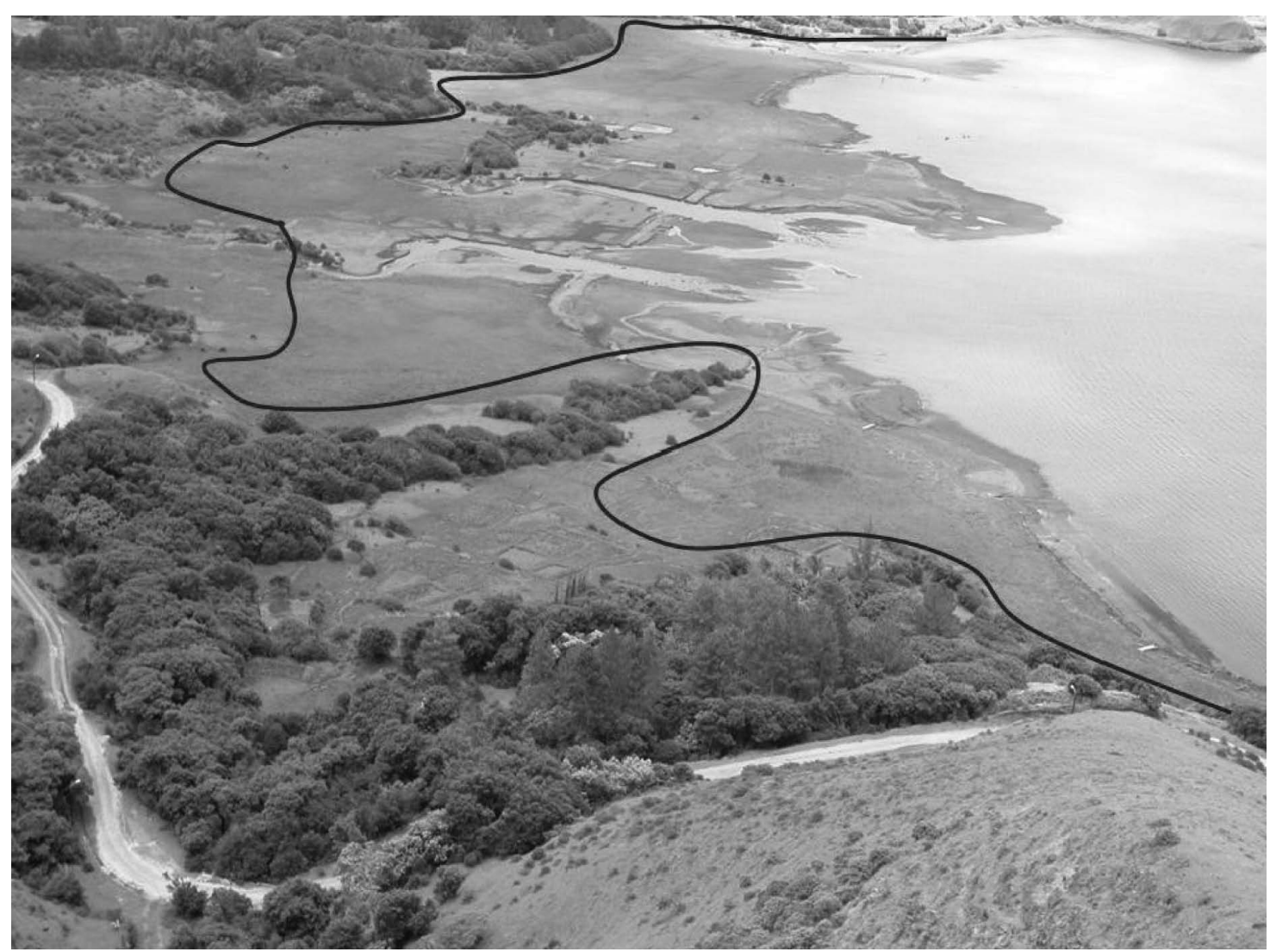

Figure 10.3. Approximate position of mid-Holocene high stand maximum marine incursion after sea-level stabilisation at Tukou (black line). Up to ca. $3 \mathrm{~m}$ of organic rich sediment has accumulated at this location above present high tide/spring tide line, marked by the interface between the marsh and the tidal flats.

The vegetation of the waterlogged marsh surface has been described by Prebble (In press). The marsh is currently dominated by introduced agricultural grasses (e.g. Paspalum subjugatum) and adventive herbs (e.g. Commelina diffusa and Ludwigia octovalvis), with some indigenous sedges (e.g. Carex spp.) and rushes (e.g. Schoenoplectus subulatus subsp. subulatus; some authors suggest that this may have been introduced to French Polynesia). The embankment on the periphery of the marsh is largely open grass with some naturalised Syzgium jambos and Psidium spp. trees (all in the Myrtaceae). Some indigenous trees are found at the site, including Talipariti tiliaceum syn. Hibiscus tiliaceus (Malvaceae) and Metrosideros collina (Myrtaceae). Hall's (1869) sketch of the site indicates that stone-wall terraces lined the upper portion of the marsh and were focused along the banks of the adjacent river channels. Some of these terrace features remain, but in a degraded state. Only one feral C. esculenta specimen was located at Tukou, with no other plant cultigens identified. The marsh is currently left for cattle and horse grazing.

\section{Methods}

\section{Multiple profiling at Tukou Marsh}

In order to determine the range of taphonomic processes affecting the pollen assemblages, and also the initial establishment of Colocasia agriculture and its spatial expansion from palynological and sedimentary proxies, a multiple profile approach was chosen. This allows for direct pollen stratigraphic correlation (sensu Clark et al. 1986). Due to the complexities of palynological analyses, multiple profiles are rarely analysed for palynological signatures. Instead, palynologists 
tend to either increase the temporal resolution of a single profile, or take single profiles in order to compare between individual depositional settings within a region. The multiple profile approach allows local or extra-local spatial variations in pollen representation to be examined in more detail (Dumayne-Peaty and Barber 1998). If a reliable absolute chronology is obtained, it also allows palynological signatures to be more precisely linked to stratigraphic processes, both spatially and chronologically.

Six cores were taken at $20 \mathrm{~m}$ intervals along a transect running through the centre of the marsh from the first core site (Core 1) at the shoreline to the embankment behind the marsh. The five cores were all taken with a D-Section corer. An attempt was made with each coring point to reach bedrock or a depth where compacted basal clays prevented further penetration. The relative position to high-tide sea level was determined from laser transit measurements. The main parameters of each core are outlined in Table 10.2.

\section{Laboratory and numerical method}

A composite stratigraphic diagram (Figure 10.4) was constructed using the program C2 Data Analysis version 1.6 (Juggins 2010). In this diagram, each core profile is vertically aligned according to relative sea level (at high tide) and its relative position from the original core site. Calibrated radiocarbon age ranges and the Bayesian depositional age/depth models are presented for each core in this diagram. Each model was processed using the program OxCal version 4.1 (Bronk Ramsey 2008). The palynological data for all of the Tukou Cores are presented in this

Table 10.2. Tukou Marsh multiple profile summary. Main features of each core are presented, including mean Bayesian ages for the key listed events. All ages were modelled using the program 0xCal 4.1 (Bronk-Ramsey 2008) of calibrated radiocarbon determinations. Mid-point estimates refer to the average age of the mean Bayesian ages presented for each event recorded at Tukou. For more details of the radiocarbon chronology and event stratigraphy see Prebble et al. (In press).

\begin{tabular}{|c|c|c|c|c|c|c|c|}
\hline Core features & Core 3 & Core 6 & Core 2 & Core 5 & Core 4 & Core 1 & Age \\
\hline Depth of core $(\mathrm{cm})$ & 318 & 250 & 400 & 250 & 250 & 652 & \\
\hline Basal clay reached & yes & no & yes & no & no & yes & \\
\hline Depth above high tide $(\mathrm{cm})$ & 300 & 243 & 196 & 161 & 111 & 20 & \\
\hline Distance from shoreline $(\mathrm{m})$ & 105 & 85 & 65 & 45 & 25 & 5 & \\
\hline $\begin{array}{l}\text { number of AMS radiocarbon } \\
\text { determinations }\end{array}$ & 3 & 4 & 5 & 2 & 4 & 6 & \\
\hline \multicolumn{8}{|l|}{ Events } \\
\hline $\begin{array}{l}\text { Depth }(\mathrm{cm}) \text { of post-European plant } \\
\text { introduction }\end{array}$ & $30-32$ & $70-72$ & $60-62$ & $48-50$ & $48-50$ & - & after AD 1825 \\
\hline Colocasia end (AD) & 1685 & 1920 & 1852 & 1816 & 1554 & - & AD 1800 \\
\hline Colocasia onset (AD) & 1170 & 1392 & 1024 & 1286 & 1098 & - & AD 1210 \\
\hline $\begin{array}{l}\text { Earliest unprecedented Microcharcoal } \\
\text { peak (AD) }\end{array}$ & 1016 & 1117 & 1024 & 1073 & 1098 & 1193 & AD 1105 \\
\hline Microcharcoal onset (BC/AD) & 241 & 585 & $-130(B C)$ & 1073 & 1002 & 1193 & $\begin{array}{l}\text { pre-human arrival } \\
\text { AD } 1263\end{array}$ \\
\hline Pandanus decline $>30 \%$ from peak (AD) & 1016 & 1254 & 1510 & 1393 & 1376 & 1401 & \\
\hline Pandanus peak (AD) & 550 & 1117 & 1364 & 1180 & 1287 & 1297 & AD 957 \\
\hline
\end{tabular}


same composite stratigraphic diagram. This examination of the Tukou core transect focuses on radiocarbon ages, charcoal particle concentrations, and Pandanus cf. tectorius and Colocasia esculenta pollen as key markers of forest clearance and agricultural expansion at the site. A more detailed analysis of all of the fossil data recorded at Tukou, including the chronological data, is in preparation.

\section{Results}

The palynological record of Tukou indicates that coastal Pandanus swamp forests expanded after about $500 \mathrm{BC}$ in response to changing sedimentary conditions following a mid-Holocene sealevel high stand (Prebble unpublished data). Within or around the period represented from the basal ages of the Tangarutu archaeological sequence, certainly after AD 1000, between $50 \mathrm{~cm}$ and $120 \mathrm{~cm}$ of colluvial sediments accumulated at different rates across Tukou Marsh. This period is represented by a rapid increase in sedimentation comparable with the accumulation rates found from deposits in the other embayments (e.g. Akatanui, Anarua and Iri). The Pandanus pollen records (Figure 10.4) indicate that swamp forest declined consistently across the site within the past 1000 years. The stratigraphy and chronology of cores 1 to 6 from Tukou have been described in the context of coastal swamp forest development (Prebble unpublished notes). Here, we outline some of the key palynological indicators for human impact and attempt to further define the stratigraphy and chronology for each core. Following this, we explore each of the cores individually in order to define some of the key ecological responses to human impacts at Tukou.

\section{Summary of palynological analysis of human activity at Tukou}

The cores are divided into four palynological zones on the basis of the major vegetation changes. In the composite stratigraphic diagram (Figure 10.4) only the upper zone (IV) is marked. This zone has been divided into two subzones (IVa and $\mathrm{IVb}$ ) on the basis of palynological marker taxa that represent the Polynesian (IVa, shaded in transparent light grey) and European periods (IVb, shaded in transparent dark grey). These subzones and the lower three zones are discussed in more detail in Prebble (unpublished notes).

\section{Charcoal particles}

The presence of high concentrations of charcoal particles in Zone IV of Core 1 is not directly tied to sedimentation or preservation. As a working hypothesis, it reflects human-induced burning at the site. In Zone IV of Core 1, counter to what might be expected, increasing charcoal concentrations overlap with increasing Pandanus pollen concentrations. These Pandanus peaks may be representative of one of the following: sediment compaction in the early part of the zone allowing for pollen to accumulate and become more concentrated with depth; or the opening of forest conditions allowing for more pollen deposition; or the possibility that Pandanus responds to burning by increased flowering and pollen production. The decline in charcoal signals in the later part of this zone also corresponds with a decrease in Pandanus pollen concentrations. This might represent a decrease in the amount of fuel available at Tukou after an initial period of burning.

The key problem identified from the analysis of the Core 1 data set is establishing the chronology for deforestation represented by Pandanus pollen decline and increases in charcoal particles alone. No radiocarbon dates were obtained from Zone IV sediments of Core 1, but the Bayesian depositional model of the radiocarbon ages that were obtained suggests that the base of Zone IV encompasses the radiocarbon chronology established from the archaeological record (indicated by the vertical grey bar within the age model histogram in Figure 10.4). 


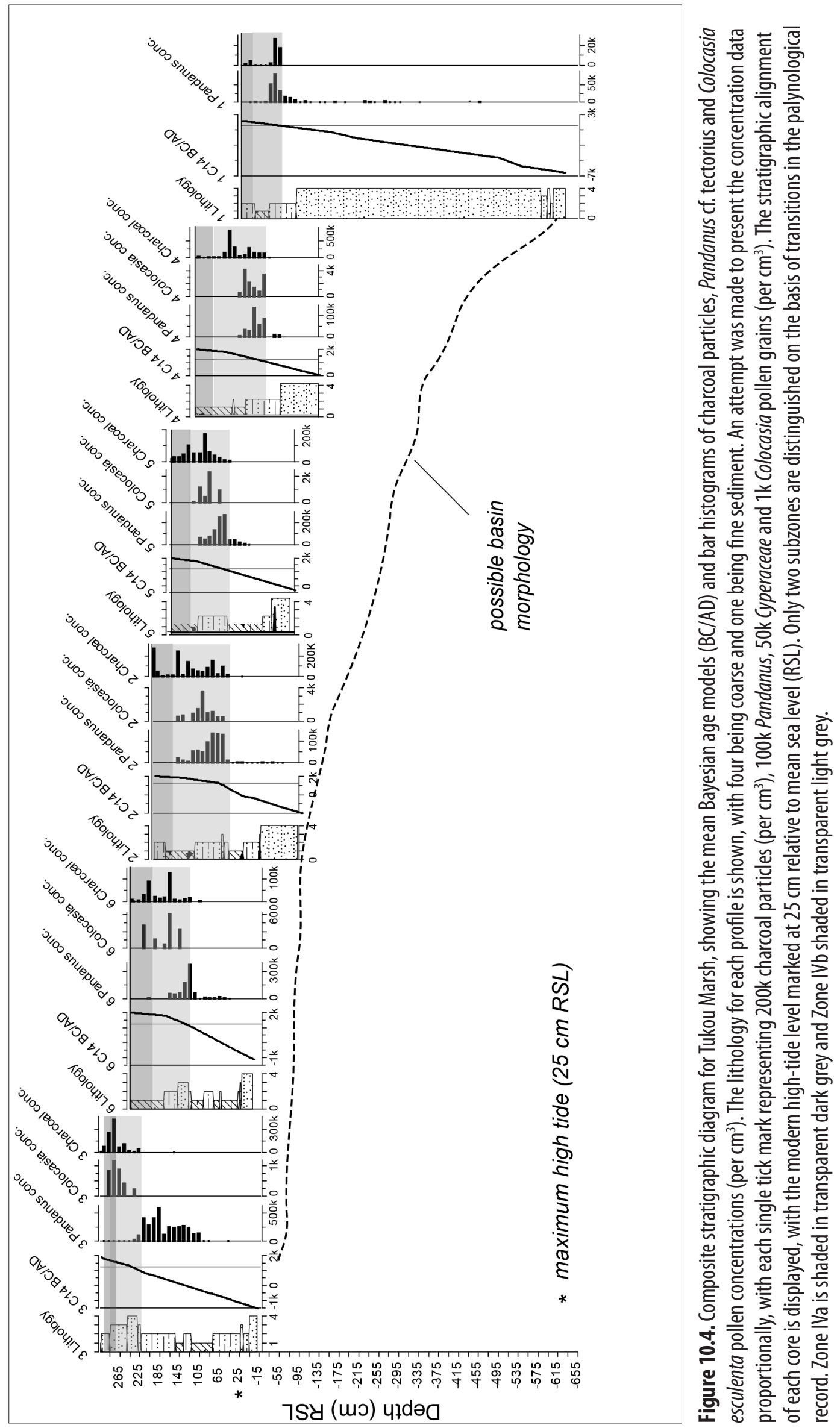


More radiocarbon ages obtained from the five additional Tukou cores (cores 2-6) better establish the chronology of charcoal particle increases, particularly of microcharcoal. The chronology for the onset of microcharcoal particle concentrations identified from pollen concentrates has been modelled using radiocarbon interpolations based on the Bayesian paradigm and generated using the program OxCal 4.1 (see Table 10.2). The earliest age obtained for the initial appearance of microcharcoal particles comes from Core 2 in the centre of the marsh, established from a direct AMS date at $130 \mathrm{BC}$, with the youngest age determined from Core 1 , at $\mathrm{AD} 1193$. The concentration of microcharcoal particles also varies considerably across the site. The highest concentrations occur in Core 6 and concentrations overall are higher in cores 2-6 than in Core 1. Differential fuel loads across the site could explain this variation in microcharcoal concentrations, but the influence of tidal action might also have reduced the amount of particle accumulation. The intensity of human activity at the site is higher towards the inland part of the marsh where evidence for past agricultural activity is most apparent and this may also explain the spatial variation in microcharcoal concentrations.

The mean Bayesian ages for the onset of microcharcoal concentrations from all of the Tukou cores are consistently older than the earliest age determination obtained from the archaeological record of Tangarutu. All of the mean Bayesian ages for peaks in microcharcoal concentrations are recorded within the archaeological chronology established for Rapa. This is quite typical of charcoal profiles in Pacific swamps and it is usually held to represent sporadic low-level charcoal production resulting from infrequent natural fires, followed by abundant charcoal production with a substantially increased rate of ignition on the arrival of people. Thunder and lightning occur infrequently at any time of the year on Rapa and could ignite grass or scrub fires during dry seasons, although such an event has not been recorded.

It is often very difficult to distinguish microcharcoal particles from blackened woody tissue that develops in the reducing environment of estuarine water. The presence of charcoal particles radiocarbon dated from the base of the cores could thus indicate either that there was no burning (the black material not being charcoal), or that burning was part of the pre-human island ecosystem, or, indeed, that charcoal had been produced from an early but transient human visit. In the absence of other human indicators, or of the chemical determination of black particles as charcoal, caution must be observed.

Initiation of agriculture: Colocasia esculenta pollen records

Apart from charcoal particle increases, no plant cultigen pollen or any unequivocal palynological signatures of human presence were identified from Tukou Core 1. Pollen from the cultigen Colocasia esculenta was identified from each of the remaining five cores from Tukou, all within Zone IV. The presence of Colocasia pollen provides a more secure indication of human presence as it could only have been derived from introduced populations. The distribution of C. esculenta in Remote Oceania is restricted by oceanic barriers (Matthews 1995, 2004) and may also be limited by the lack of suitable hydrological environments for it to establish without human intervention. C. esculenta pollen has now been identified in numerous pollen records across the Indo-Pacific, suggesting the records from Rapa are not anomalous.

The composite stratigraphic diagram (Figure 10.4) shows that, like Pandanus pollen and microcharcoal particles, C. esculenta pollen concentrations are differentially represented across the site. The highest concentrations are found in cores 2 and 4 in the central part of the marsh, with the lowest concentrations found in the most inland core (Core 3). This trend could be explained by Colocasia cultivation activity whereby plants are actively prevented from flowering during cultivation, mainly by corm harvesting before flowering. C. esculenta is known to be a 
poor pollen producer, and it is relatively rare in the pollen record (e.g. Haberle 1994; Prebble unpublished data). The high concentrations of C. esculenta pollen represented in some cores may reflect a response to the increased seasonality of the more subtropical climate of Rapa. Alternatively, high C. esculenta pollen concentrations in sediments may reflect the high local presence of feral plant populations outside of immediate cultivation that may have been allowed to set flowers. One hypothesis is that this may have been an integral strategy in the early establishment of Colocasia crops, allowing for genetic exchange and the extension of cultivar diversity in an ecosystem different from the homeland of the first Polynesians to arrive on the island.

The mean Bayesian ages for the onset of C. esculenta pollen from cores 2-6 (see Table 10.2) all fall in an age bracket that overlaps the earliest age determination obtained from the archaeological record of Tangarutu (Chapter 11). Most of these mean ages are older than expected and this may reflect the loose chronological control for the first appearance of $C$. esculenta pollen in three of the five cores (cores 3, 4 and 5). The onset of C. esculenta in Core 2 is constrained by four AMS ages and may provide the most reliable age for the onset of cultivation on Rapa at $1024 \mathrm{AD}$, but this still appears to be older than expected.

None of the mean Bayesian ages are more than 200 years older than the earliest archaeological determination for the island. They could be correct. It is possible that the process of taro cultivation resulted in the mixing of sediments. Modern digging of wet-fields usually involves the turning of between $20 \mathrm{~cm}$ and $30 \mathrm{~cm}$ of topsoil and this process could have resulted in older organic material being incorporated into the planting horizon. Yet, it is apparent that no chronological inversions were noted among radiocarbon ages in any of the six profiles examined. This suggests that the swamp was continually accumulating sediment and organic materials and that if sediment mixing did occur, it was minimal.

With the exception of Core 4, all of the peaks in C. esculenta pollen occur in the latter part of Zone IVa. With a mean Bayesian age of $A D$ 1231, the sample showing first appearance of $C$. esculenta pollen in Core 4 also has the highest concentrations. If this age is accepted, the early presence of high pollen concentrations of $C$. esculenta in the most shoreward core site might reflect the proposition, above, of high local presence of feral Colocasia populations outside areas of immediate cultivation. Later in the sequence, certainly by Zone IVb across most of the cores, Colocasia pollen drops out of the record, possibly representing a change in land-use practices at the site. It is possible that harvesting of Colocasia intensified to the point where both cultivated and feral plants were prevented from flowering. This could also represent the abandonment of taro field cultivation at Tukou, which was apparent by the time Hall arrived on the island in 1864. Another alternative is that with the introduction of feral grazing animals, including goats, cattle and horses, feral populations of Colocasia may have been browsed to the point where flowering was prevented. Few feral specimens survive on the island today and no flowers have been recorded or collected on the island by any visiting botanist (Jean-Yves Meyer pers. comm.).

\section{Sedimentary deposits from other embayments on Rapa}

Small sedimentary catchments are located at the base of windward boulder and leeward sandy beach embayments of the island (Figure 10.5; see Figure 10.1 for locations). The more deeply incised windward embayments are characterised by higher energy fluvial/alluvial systems, forming in places of extensive swamp deposits adjacent to abandoned Colocasia esculenta terraced pondfields. These swamps possess highly organic clay and silt deposits, preserving botanical remains. The sedge Schoenoplectus subulatus var. subulatus dominates the vegetation of most of these swamp sites. The swamp deposits were cored with the intent of reaching basal 
clays or bedrock from Akatanui ( $2 \mathrm{~m}$ deep Core 1; Figures 10.5 and 10.6), Iri (3 m deep Core 1; Figure 10.7) and Anarua (1.8 m deep Core 1; Figure 10.8). Magnetic susceptibility (K) measurements from these cores provide some indication of the extent of organic accumulation at each site. Radiocarbon ages were obtained from charcoal or black organic pieces found in the basal sediments of these cores, revealing 2 $\sigma$ ages of AD 1420-1460 (UCIAMS 2194), AD 620-1280 (ANU 12154), and AD 1190-1950 (ANU 12155) respectively. The radiocarbon date from Akatanui Core 1 corresponds to the archaeological chronology established from the Tangarutu rockshelter (Chapter 11) and suggests that these sediments were deposited during the early colonisation phase of the island. The age ranges of the two dates from Iri and Anarua are insufficient to indicate the precise timing of sediment deposition. The sediments found at the base of the $3 \mathrm{~m}$ core from Iri are lagoon sediments rich in marine diatoms (Jan Finn pers. comm. 2005), suggesting that the terrestrial organic sediments had accumulated at the site within the past 1000 years. An additional $2.5 \mathrm{~m}$ core was obtained and radiocarbon dated from an upland swamp deposit above Anatakuri Bay, at Otaikui (see Figure 10.9). The swamp appears to be formed behind a landslip and little evidence remains of any agricultural features. The vegetation of the swamp consists mostly of Schoenoplectus. A fragment of charcoal from the core gave a modern determination (ANU 12157), suggesting these sediments were recently deposited.

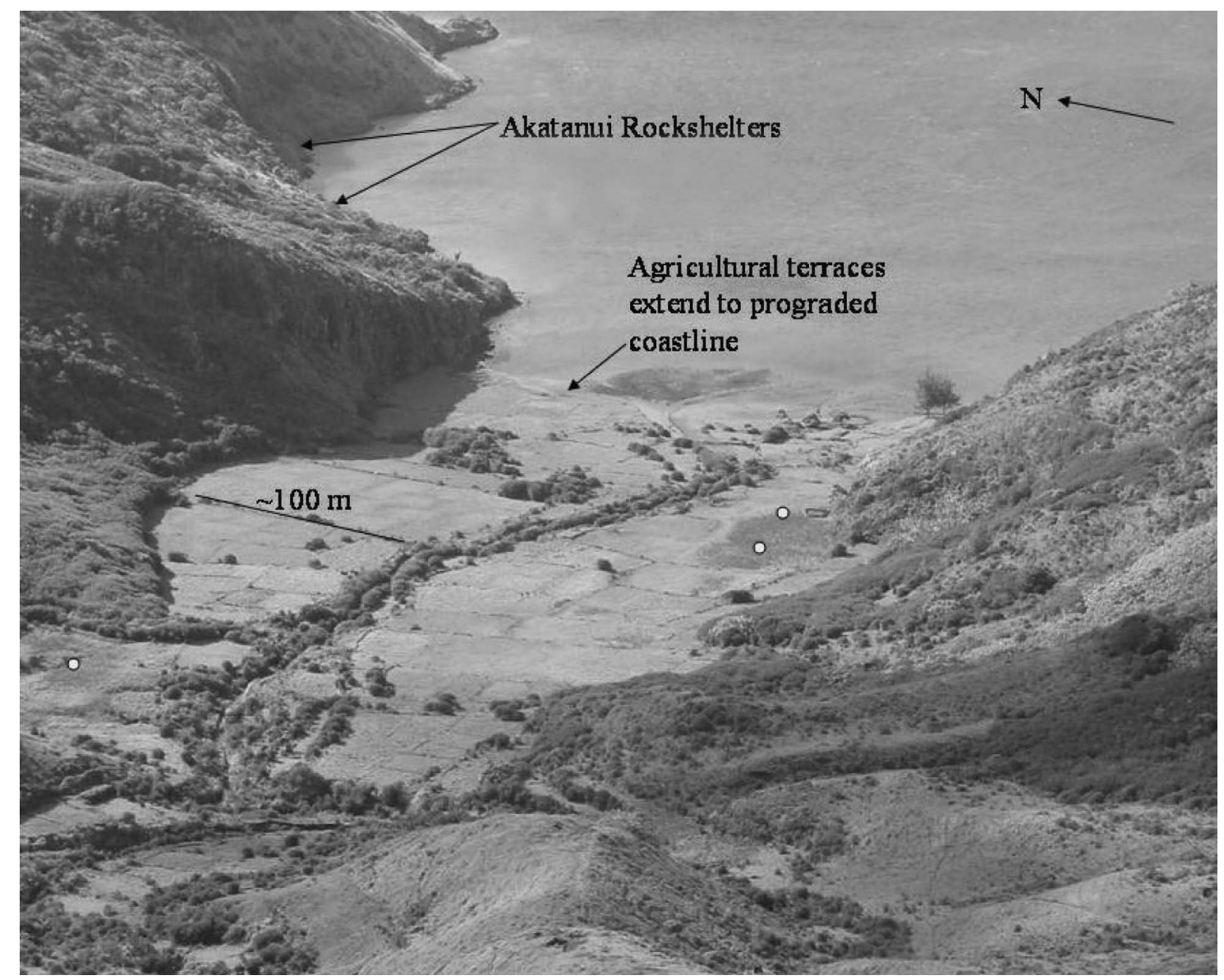

Figure 10.5. Photograph of Akatanui, showing the position of two rockshelters, the extent of abandoned agricultural terraces and the location of three coring locations (white dots), only one mentioned in the text. See Figure 10.1 for location of Akatanui Bay. Photograph D.J. Kennett. 


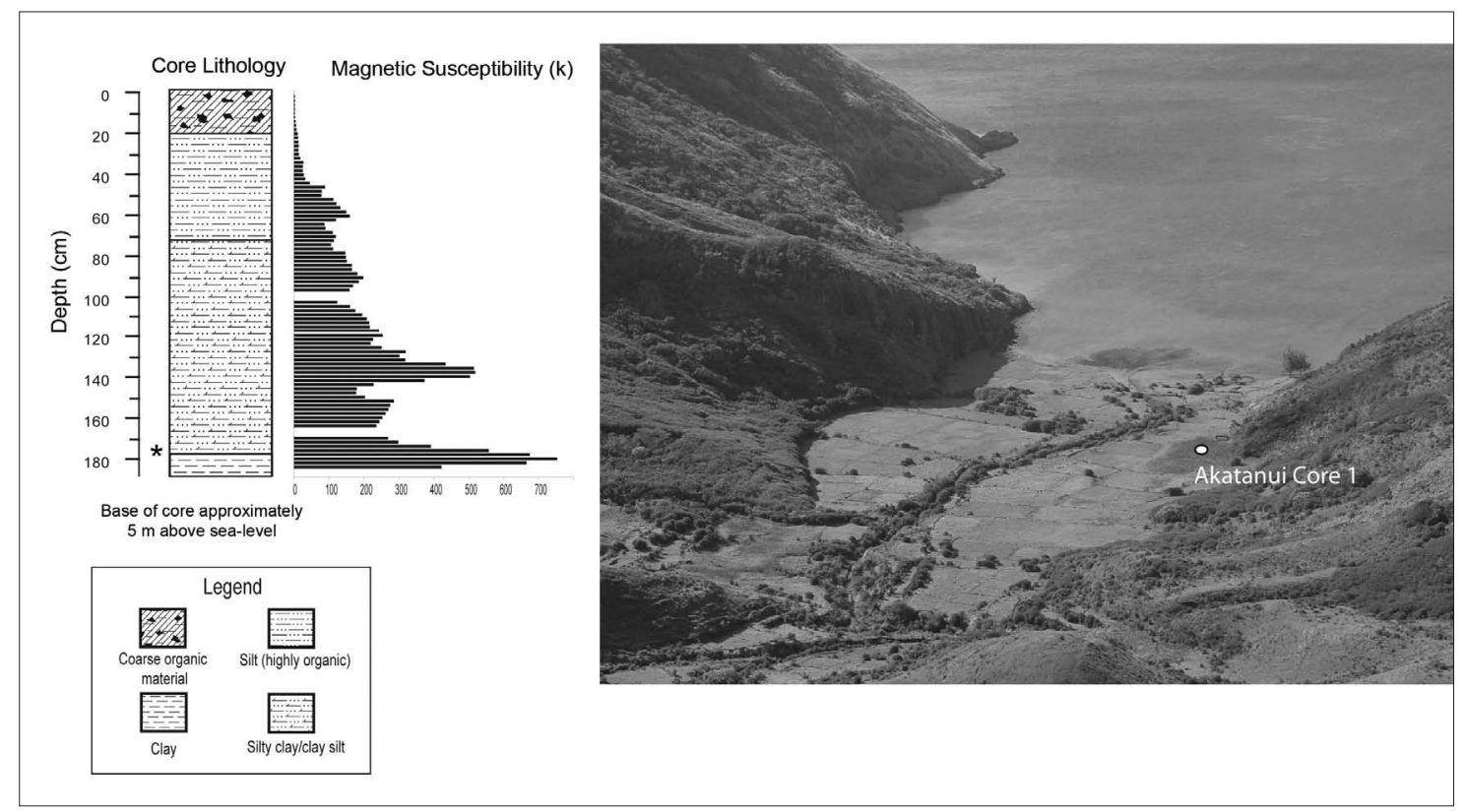

Figure 10.6. Sediment lithology and magnetic susceptibility measurements (K) of the Akatanui Core 1 are shown. *marks location of radiocarbon sample AMS ANU-12157 (charcoal).

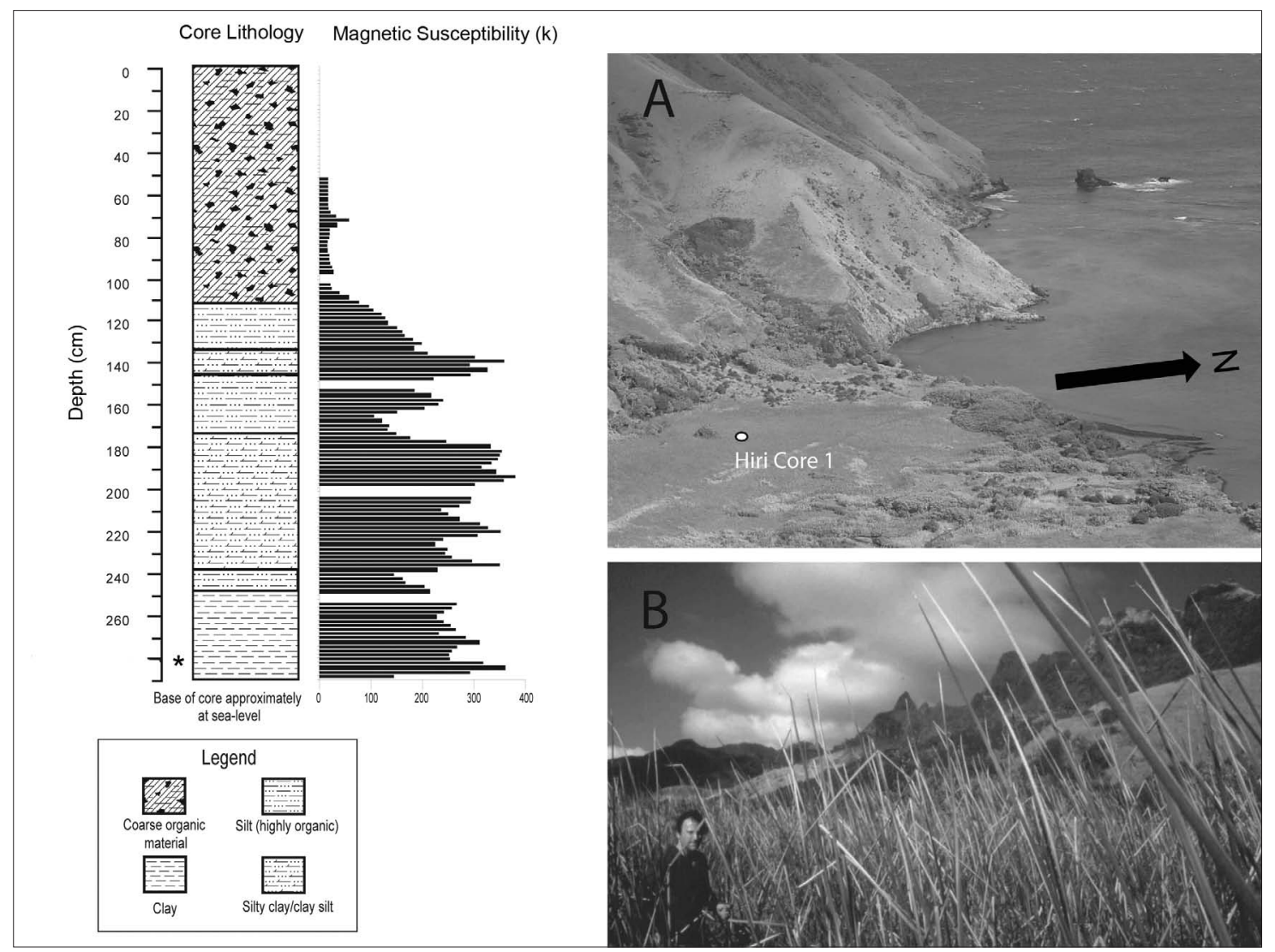

Figure 10.7. Sediment lithology and magnetic susceptibility measurements (K) of the Iri Core 1 are shown (left). To the right are photographs of Iri. A. shows the extent of Iri wetland and the position of Hiri Core 1 (white dot). B. shows the author at the core site among a dense stand of Schoenoplectus subulatus var. subulatus. *marks location of radiocarbon sample AMS ANU-12157 (charcoal). See Figure 10.1 for location of Iri Bay. Photographs D.J. Kennett and A. Anderson. 


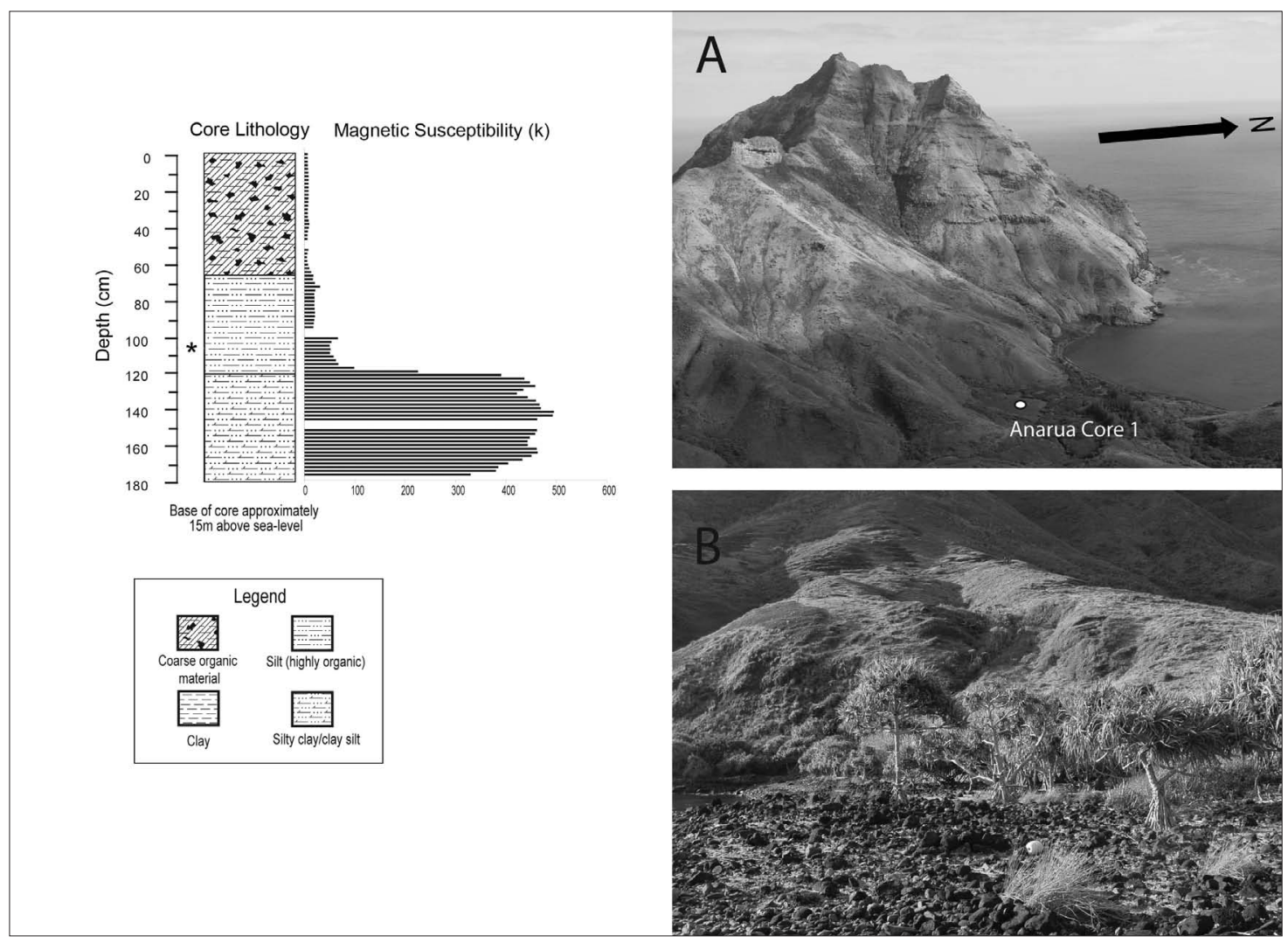

Figure 10.8. Sediment lithology and magnetic susceptibility measurements $(K)$ of the Anarua Core 1 are shown. To the right are photographs of Anarua. A. shows the extent of Anarua wetland and embayment and the position of Anarua Core 1 (white dot). B. shows the boulder beach at the head of Anarua backed by Pandanus tectorius trees. *marks location of radiocarbon sample AMS ANU-12157 (charcoal). See Figure 10.1 for location of Anarua Bay. Photographs D.J. Kennett and A. Anderson.

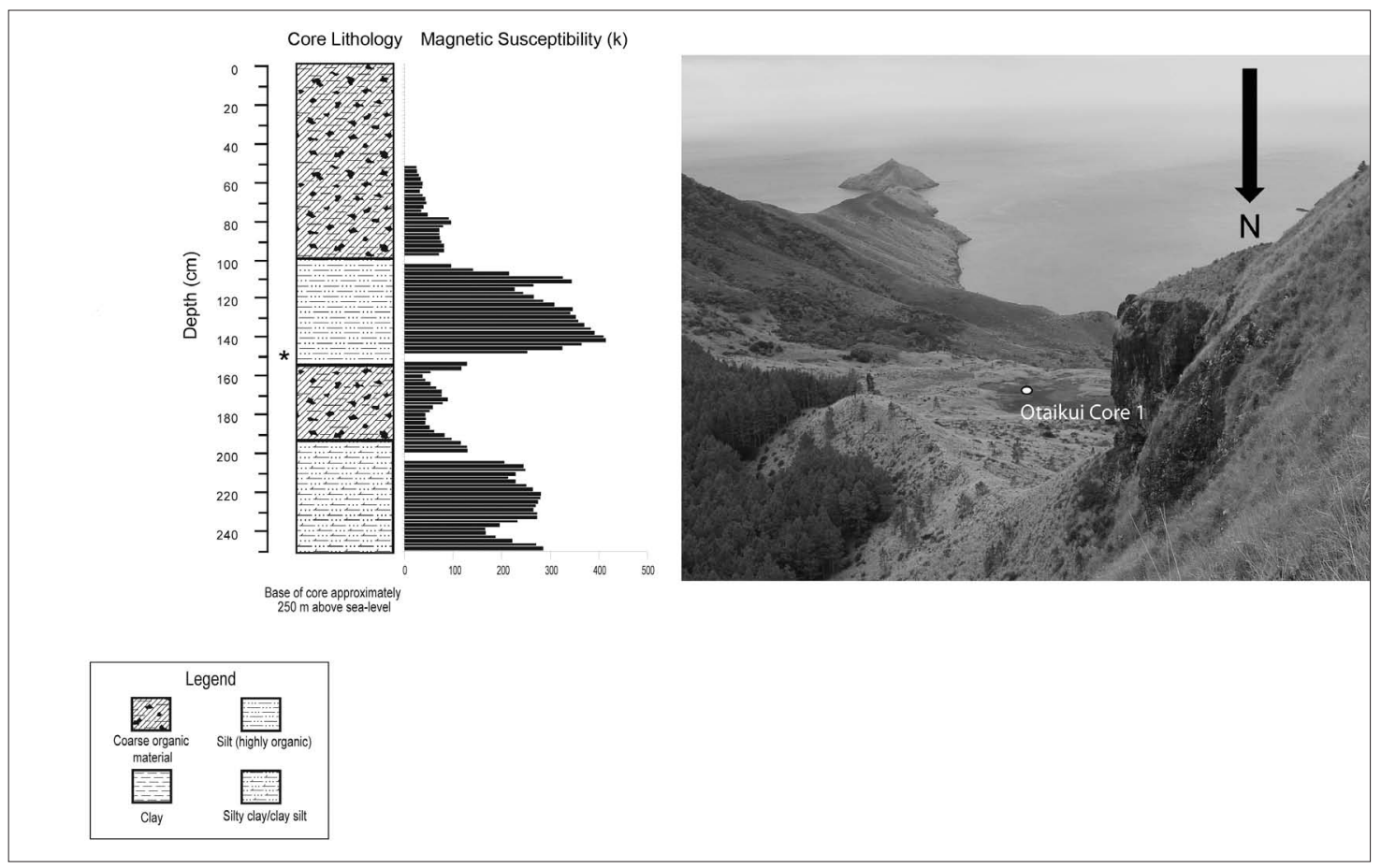

Figure 10.9. Sediment lithology and magnetic susceptibility measurements $(K)$ of the Angatakuri Core 1 (Otaikui Swamp) are shown. To the right is a photograph of Angatakuri that shows the extent of the wetland and the position of the core (white dot). * marks location of radiocarbon sample AMS ANU-12157 (charcoal). See Figure 10.1 for location of Angatakuri Bay. Photograph D.J. Kennett. 


\section{Summary}

The multiple profile approach revealed an uneven response of pollen deposition to sedimentary influxes, whereby pollen zones could be identified but were represented in differing size units. What is more striking are the direct indications for post-contact introduction of a range of seral weed taxa (Prebble unpublished data). The initial presence of these taxa corresponds to distinctive pollen zones that extend to the modern marshland surface. On Rapa, the earliest anthropogenic pollen zone, described as a Polynesian phase, is characterised by C. esculenta pollen, a suite of other potential introduced taxa (e.g. Aleurites moluccana and Erythrina variegata), the onset of high charcoal particle concentrations, declines in arboreal taxa including the extirpation or extinction of Arecaceae palm pollen, and an associated increase in fern, grass and other herb taxa. The upper European phase palynofacies are characterised by a decline of C. esculenta pollen, further local declines or extirpations of arboreal taxa (e.g. Pandanus tectorius) and the initial presence and subsequent increase of a range of introduced weed taxa (e.g. Ludwigia octovalvis, Commelina diffusa and Sonchus oleraceus). In addition, high charcoal particle concentrations continue with a further increase in fern, grass and other herb taxa. Such a distinctive pattern of pollen and spore deposition has only been found in a few other sites in island Remote Oceania (e.g. Kawainui Marsh, O'ahu, Ward in Hammatt et al. 1990; Alenaio Swamp, Hawai'i, Wickler and Ward 1992; Maunawili Swamp, O’ahu, Athens and Ward 1997).

\section{Colocasia esculenta at initial colonisation?}

We have noted a number of problems in the examination of agricultural swamp profiles from back-beach deposits on Polynesian high islands. The mixing of swamp profiles during the digging and planting process may have resulted in the mixing of organic materials, possibly generating older than expected radiocarbon determinations. This issue could be resolved by further high-resolution radiocarbon dating. Despite these problems, there is great potential for understanding the timing of crop introduction and the rate of expansion using the multiple profiling method employed in this study. It is by no means conclusive, but Colocasia may have been planted at Tukou at the time of, or soon after, initial human arrival. The swamp appears to have been planted from near the shoreline to the hillside embankment, covering an area of more than 2 ha. Colocasia pollen is continuously represented up to the period of European contact, when the swamp was either infrequently used or overrun by feral animals. Prebble (unpublished data) has identified hydrological changes on the swamp from invertebrate and seed assemblages that may represent the expansion of terraced pondfields.

The work at Tukou Swamp suggests that early deployment of agriculture within the colonisation era in places where it was introduced at that time may not be too difficult to find, contrary to the pessimism expressed by Addison (2008:151):

Finding archaeological evidence for the sequence of agricultural development ... will be challenging. The earliest use of natural wetlands for raised-bed cultivation is unlikely to have left any archaeological signature. Early pondfield systems are likely to have been small, but they would have been built in the easiest areas - areas that have probably seen relatively constant use since initial colonization. This subsequent use will have obscured most traces of the earliest pondfields.

We agree that there are problems in untangling and dating evidence from sites that have often been used repeatedly, perhaps continuously, but taking an archaeological approach to sedimentary history coupled with a multiple profile coring method may help to resolve these. Our work shows that the natural wetlands on Rapa were probably used for Colocasia production 
early, extensively and continuously and that the swamp profiles examined hold informative signatures of agricultural activity. We cannot distinguish raised bed or pondfield systems from the evidence presented, although hydrological proxies do suggest that pondfields were constructed later in the sequence. We agree with Addison that Colocasia would have been cultivated in the easiest areas. These were the Pandanus swamp forests that were easily and rapidly cleared by fire, creating an immediate soil horizon suitable for crop production.

\section{References}

Addison, D.J. 2008. The changing role of irrigated Colocasia esculenta (taro) on Nuku Hiva, Marquesas Islands: from an essential element of colonization to an important risk-reduction strategy. Asian Perspectives 47:139-155.

Anderson, A.J. 1994. Paleoenvironmental evidence of island colonization: A response. Antiquity 68:845-847.

Anderson, A.J. 1995. Current approaches in East Polynesian colonization research. Journal of the Polynesian Society 104:110-132.

Anderson, A.J. 2003. Initial human dispersal in Remote Oceania: pattern and explanation. In: Sand, C. (ed), Pacific archaeology: assessments and prospects, 71-84. Noumea: Service des Musées et du Patrimoine.

Anderson, A.J. 2009a. The rat and the octopus: initial human colonization and the prehistoric introduction of domestic animals to Remote Oceania. Biological Invasions 11:1503-1519.

Anderson, A.J. 2009b. Changing archaeological perspectives upon historical ecology in the Pacific islands. Pacific Science 63:747-757.

Anderson, E. 1952. Plants, man, and life. University of California Press.

Ash, J. and Ash, W. 1984. Freshwater wetland vegetation of Viti Levu, Fiji. New Zealand Journal of Botany 22:377-391.

Athens, J.S. and Ward, J.V. 1993. Environmental change and prehistoric Polynesian settlement in Hawai' i. Asian Perspectives 32:205-223.

Athens, J.S. and Ward, J.V. 1997. The Maunawili core: prehistoric inland expansion of settlement and agriculture, O'ahu, Hawai' i. Hawaiian Archaeology 6:37-51.

Bronk Ramsey, C. 2008. Deposition models for chronological records. Quaternary Science Reviews $27: 42-60$.

Clark, J.S., Overpeck, J.T., Webb III, T. and Patterson III, W.A. 1986. Pollen stratigraphic correlation and dating of barrier-beach peat sections. Review of Palaeobotany and Palynology 47:145-168.

Conte, E. and Payri, C. 2006. Present-day consumption of edible algae in French Polynesia: A study of the survival of pre-European practices. Journal of the Polynesian Society 115:77-94.

Davidson, J. and Leach, F. 2001. The strandlooper concept and economic naivety. In: Clark, G.R., Anderson, A.J. and Vunidilo, T. (eds), The Archaeology of Lapita dispersal in Oceania. Terra Australis 17:115-124.

Davies, J. Rev. 1827. Extracts from the journal of a visit to the islands of Rapa (or Oparo), Raivavai, and Tupuai etc (July and October, 1927). Quarterly chronicle of transactions of the London Missionary Society 3:323-332, 353-361.

Dumayne-Peaty, L. and Barber, K. 1998. Late Holocene vegetational history, human impact and pollen representativity variations in northern Cumbria, England. Journal of Quaternary Science 13:147-164.

Ellison, J. 1991. The Pacific palaeogeography of Rhizophora mangle L. (Rhizophoraceae). Botanical Journal of the Linnean Society 105:271-284.

Flenley, J.R. 1979. Stratigraphic evidence for environmental change on Easter Island. Asian Perspectives 22:33-40. 
Flenley, J.R. and King, S.M. 1984. Late Quaternary pollen records from Easter Island. Nature 307:47-49.

Flenley, J.R., King, S.M., Jackson, J. and Chew, C. 1991. The Late Quaternary vegetational and climatic history of Easter Island. Journal of Quaternary Science 6:85-115.

Fosberg, F.R. 1956. Military geography of northern Marshall Islands. Tokyo: Intelligence Division Office of the Engineer, Headquarters.

Fosberg, F.R. and St. John, H. 1934. Check list and field notebook of the plants of Southeastern Polynesia: Society Islands, Tuamotus, Austral Islands, Rapa. Honolulu.

Haberle, S. 1994. Anthropogenic indicators in pollen diagrams: problems and prospects for late Quaternary palynology in New Guinea. In: Hather, J.G. (ed), Tropical archaeobotany: Applications and new developments, 172-201. Routledge, London.

Hall, J.V. 1869. On the island of Rapa. Transactions and Proceedings of the New Zealand Institute $1: 128-134$.

Hammatt, H.H., Shideler, D.W., Chiogioji, R. and Scoville, R. 1990. Sediment coring in Kawainui Marsh, Kailua, O'ahu, Ko'olaupoko. Honolulu.

Hardy, K., Blakeney, T., Copeland, L., Kirkham, J., Wrangham, R. and Collins, M. 2009. Starch granules, dental calculus and new perspectives on ancient diet. Journal of Archaeological Science 36:248-255.

Horrocks, M. and Bedford, S. 2005. Microfossil analysis of Lapita deposits in Vanuatu reveals introduced Araceae (aroids). Archaeology in Oceania 40:67-74.

Horrocks, M., Bedford, S. and Spriggs, M. 2009. A short note on banana (Musa) phytoliths in Lapita, immediately post-Lapita and modern period archaeological deposits from Vanuatu. Journal of Archaeological Science 36:2048-2054.

Jayalekshmy, A. and Mathew, A.G. 1990. Changes in the carbohydrates and proteins of coconut during roasting. Food Chemistry 37:123-134.

Jones, R. and Spriggs, M. 2002. Theatrum Oceani: Themes and Arguments concerning the Prehistory of Australia and the Pacific. In: Cunliffe, B., Davies, H. and Renfrew, C. (eds), Archaeology: the Widening Debate, 245-294. Oxford University Press for the British Academy, London.

Juggins, S. 2010. C2 Data Analysis. Newcastle.

Kennett, D.J., Anderson, A.J., Prebble, M., Conte, E. and Southon, J. 2006. Prehistoric human impacts on Rapa, French Polynesia. Antiquity 80:340-354.

Kirch, P.V. 1982. Ecology and the adaption of Polynesian agricultural systems. Archaeology in Oceania $17: 1-6$.

Kirch, P.V. 2002. On the road of the winds. University of California Press, Berkeley.

Kirch, P.V., Steadman, D.W., Butler, V.L., Hather, J. and Weisler, M.I. 1995. Prehistory and human ecology in Eastern Polynesia: Excavations at Tangatatau Rockshelter, Mangaia, Cook Islands. Archaeology in Oceania 30:47-65.

Kirch, P.V. and Green, R.C. 2001. Hawaiki, ancestral Polynesia: an essay in historical anthropology. Cambridge University Press.

Lamb, W.K. (ed), 1984. George Vancouver, 1803, A Voyage of Discovery to the North Pacific Ocean and Round the World 1791-1795, Volume I. The Hakluyt Society, London.

Massey, J.E. 1979. The diatoms of contemporary and ancient sediments from Lake Waiau, Hawaii, and their geochemical environment. Review of Palaeobotany and Palynology 27:77-83.

Matthews, P.J. 1995. Aroids and the Austronesians. Tropics 4:105-126.

Matthews, P.J. 2004. Genetic diversity in Taro and the preservation of culinary knowledge. Ethnobotany Research and Applications 2:55-71.

McGlone, M.S. and Wilmshurst, J.M. 1999. Dating intial Maori environmental impact in New Zealand. Quaternary International 59:5-16.

McGlone, M., Wilmshurst, J.M. and Leach, H. 2005. An ecological and historical review of bracken (Pteridium esculentum) in New Zealand, and its cultural significance. New Zealand Journal of Ecology 29:165-184. 
Meyer, J.-Y. 2002. Rapport de mission de l'expédition scientifique à Raivavae et Rapa (Australes) du 18 Novembre au 20 Décembre 2002. Papeete.

Prebble, M. In press. The palaeobotanical record of Rapa (French Polynesia): phytogeographic implications for the Austral Archipelago. In: Meyer, J-Y. (ed), Biodiversity of the Austral Islands.

Prebble, M. and Dowe, J.L. 2008. The late Quaternary decline and extinction of palms on oceanic Pacific islands. Quaternary Science Reviews 27:2546-2567.

Prebble, M. and Wilmshurst, J. 2009. Detecting the initial impact of humans and introduced species on island environments in Remote Oceania using palaeoecology. Biological Invasions 11:1529-1556.

Prebble, M.P., Anderson, A. and Kennett, D.J. In press. Forest clearance and agricultural expansion on Rapa, Austral Archipelago, French Polynesia. The Holocene.

Selling, O.H. 1948. Studies in Hawaiian pollen statistics, Part III: on the late Quaternary history of the Hawaiian vegetation. Vol. 39. Honolulu.

Shineberg, D.E. 1986. Archibald Menzies' account of the visit of the Discovery to Rapa and Tahiti, 22 December 1791-25 January 1792. Pacific Studies 9:59-102.

Smith, A.C. 1979. Flora Vitiensis Nova. Vol. 1. Pacific Tropical Botanic Garden, Lawai.

Stokes, J.F.G. n.d. Ethnology of Rapa. B.P. Bishop Museum, Honolulu.

Stone, B.C. 1988. Notes on the genus Pandanus (Pandanaceae) in Tahiti. Botanical Journal of the Linnean Society 97:33-48.

Valentin, F., Buckley, H.R., Herrscher, E., Kinaston, R., Bedford, S., Spriggs, M., Hawkins, S. and Neal, K. 2010. Lapita subsistence strategies and food consumption patterns in the community of Teouma (Efate, Vanuatu). Journal of Archaeological Science 37:1820-1829.

Wickler, S. and Ward, J.V. 1992. Archaeological and paleoenvironmental investigations of Alenaio stream flood control project, Hilo, Hawaii Island. Honolulu.

Wilson, J., Hardy, K., Allen, R., Copeland, L., Wrangham, R. and Collins, M. 2010. Automated classification of starch granules using supervised pattern recognition of morphological properties. Journal of Archaeological Science 37:594-604. 